\title{
Організація та функціонування Залізничних військ Західно-Української Народної Республіки в 1918-1919 рр.
}

Słowa kluczowe: wojska kolejowe, infrastruktura kolejowa, ZURL, Armia Halicka, pociągi opancerzone.

Key words: railway troops, railway infrastructure, ZUNR (West Ukrainian People's Republic), Galician Army, armoured trains.

\section{Organizacja Wojsk Kolejowych Zachodnioukraińskiej Republiki Ludowej 1918-1919.}

W artykule poruszono kwestie dotyczące stworzenia i rozwoju wojsk kolejowych ZURL. Opisano działalność struktur kolejowych (Kolejowy Urząd Wojskowy, Kolejowy kureń - później warsztat (ukr. Depo), dokonano analizy najważniejszych problemów organizacji służby kolejowej zarówno w Galicji, jak i na Nadnieprzu: problem powojennej odbudowy infrastruktury kolejowej, problem transportowania wojsk byłej rosyjskiej i austro-węgierskiej armii, brak kwalifikowanych pracowników, węgla i drewna, problemy z zaopatrzeniem. Istotnym elementem struktury wojsk kolejowych były siły opancerzone, a mianowicie pociągi opancerzone. W większości wypadków własnością Armii Halickiej w Galicji były pociągi opancerzone o prymitywnej konstrukcji. Na Naddnieprzu udało się zdobyć rosyjskie wzorce fabryczne. Pociągi opancerzone brały udział zarówno w operacjach ofensywnych, jak i obronnych.

The organization of the Galician Army's railway troops 1918-1919.

The creation and the development of the Galician Army's railway troops are described. Activity of the railway structures is considered (Railway Military Council, Railway Kuren, afterwards - Depot). Main problems, which railroads had to solve during organization of their service in the Galicia and Naddniprianschyna (Great Ukraine) are analysed. Among them: problems with the post-war renewal of the railway 
infrastructure, lack of skilled workers, coal and wood, problems with food providing. Armoured railroad cars, especially armoured trains, were an important part of the railway troops. Galician Army in Galicia mostly had an armoured trains of primitive construction, produced by their own. In the Naddniprianschyna it was succeded to take Russian plant samples. Armoured trains were used to support offensive and defensive operations.

\section{Діяльність залізничної адміністрації на теренах Гали-} чини і Наддніпрянщини

Одним із найважливіших завдань, які постали перед урядом молодої Західноукраїнської держави, було налагодження повноцінного залізничного сполучення. Від його злагодженого функціонування залежало транспортування нафти, продовольства, особового складу армії, військової амуніції, пересування бронепотягів, що безпосередньо впливало на обороноздатність Республіки.

За півстоліття на території Галичини австрійській владі вдалось прокласти й ввести в експлуатацію 40 залізничних шляхів, загальною протяжністю майже 1,5 тис. км, понад 2 тис. пасажирських, 11 тис. вантажних вагонів та 200 паротягів. Бойові дії, що точилися тут в роки Першої світової війни, спричинились до знищення майже усієї інфраструктури: чимало ділянок залізничного полотна було ушкоджено, зруйновано станції, вокзали, мости, частину рухомого складу ${ }^{1}$. Тому повоєнна відбудова краю і відновлення залізничної мережі, стало першочерговим завданням до вирішення урядом ЗУНР. Розпорядженням Державного Секретаріату (ДС) в середині листопада 1918 р. інженера Івана Мирона призначено відповідальним за відбудову залізничного сполучення на підконтрольних українцям територіях. Вже незабаром він став Державним Секретарем Шляхів. У розбудові

${ }^{1}$ В. Ортинський, Силові структури Західно-Української Народної республіки, Львів 2004, s. 290-291. 
залізничної служби активну участь брав і урядовець Падох. Останній особливо відзначився у травні 1919 р. коли організував евакуацію потягів 3 державним та військовим майном ЗУНР в райони не зайняті поляками ${ }^{2}$.

Вже на початку листопада 1918 р. робота Державного Секретаріату Шляхів (ДСШ) гальмувалася через нестачу професійних кадрів на залізницях. Нагальною була потреба не лише у працівниках депо, а й у машиністах. Самотужки вирішити усі існуючі проблеми галичани не мали змоги. Частково у цьому допомагало Міністерство Шляхів УНР у Києві, яке у терміновому порядку відправило декілька десятків машиністів та перейняло на себе технічне обслуговування двох шляхів сполучення. Водночас до Галичини прибували залізничники-українці з Буковини, що рятувались від румунської окупації. Щоправда цих кроків було недостатньо. Окрім того ДСШ був змушений наймати польських спеціалістів на пільгових умовах, які в свою чергу саботували роботу залізниць і всіляко підтримували антиукраїнські настрої серед населення. Робив ДСШ і самостійні кроки з підготовки необхідних кадрів. Так, у Тернополі планувалося відкрити тримісячні курси стажерів ${ }^{3}$. Однак чи вдалося їх організувати - невідомо.

Після втрати Львова 21 листопада 1918 р. головним залізничним вузлом став Станіславів. Цього ж дня ДС військових справ звернувся до ДС закордонних справ з приводу переправи українських і іноземних військ через кордони республіки і з території Угорщини. Найбільша проблема існувала $з$ транспортуванням угорських військ. Тому ДС закордонних справ планував звернутись до угорського уряду, аби ті приготували більше вагонів на кінцевих станціях Лавочне-Керешмезе. Також міністерство

2 О. Міхула, Державні залізниці 3.О.У.Н.Р., “Літопис Червоної Калини” 5/1935, s. 4.

${ }^{3}$ О. Реєнт, О. Рубльов, Українські визвольні змагання 1917-1921 рр., Київ 1999, t. 10, s. 278. 
просило допомоги у транспортуванні 1700 українських моряків, що знаходились на території Угорщини 4 . Загалом відповідно до рапорту польського майора Тобачиньського від 9 січня 1919 р. в Будапешті і на інших станціях військовиків незалежно від їх національності буквально грабували, відбираючи окрім озброєння увесь одяг і продовольство. Такий факт мав місце з 35 полком українських стрільців з Коломиї, якого пограбували на станції Гатвань. Така ж участь спіткала кілька інших українських транспортів в яких знаходилось по 100-200 вояків в першій половині грудня 1919 р. Їх також пограбували і після цього висилали у напрямку лінії Лавочне-Стрий. За твердженням майора Тобачиньського угорці неприхильно ставилися до українців і відхиляли будь-які пропозиції, що надходили від останніх. До польської сторони були привітні і всіляко йшли на контакт 5 .

Зміна оперативної ситуації на фронті спричинила переведення усього пасажирського і вантажного руху на лінію СтрийХодорів-Тернопіль. Як згадував Льонгин Цегельський, в цей час в Галичині “потяги йшли черепашим ходом, стояли по дорозі цілими годинами “роблячи пару””. Причиною таких зупинок став банальний брак вугілля, яке в умовах польсько-української війни припинили постачати зі Шльонська ${ }^{6}$.

3 часом, аби пожвавити залізничний рух, у січні 1919 р., локомотиви вдалось переробити під використання нафти і дров. Однак це ще більше ускладнило ситуацію, адже виникла потре-

\footnotetext{
${ }^{4}$ Biblioteka Narodowa [dalej: BN], Kolekcija dokumentiw Naukowoho towarystwa imeni T. Szewczenka, MF 87299, Państwowy Sekretariat Spraw Wojskowych. Sprawy kadrowe korpusu oficerskiego i podoficerów Ukraińskiej Armii Galicyjskiej. Organizacja Stużby Kwatermistrzowskiej, k. 61.

${ }^{5}$ Archiwum Akt Nowych [dalej: AAN], Warszawa, nr 45, Kolekcje opracowań i odpisów dokumentów dotyczących stosunków Polski z Litwą, Łotwą, Rosyjską Republiką Radziecką, Ukrainą, sygn. 57, Odpis do Ministerstwa spraw zewnętrznych. Raport oficera łącznikowego w Budapeszcie majora Tobaczyńskiego dnia 9.I.1919, k. 120-121.

${ }^{6}$ Л. Цегельський, Від легенд до правди, Львів 2003, s. 123.
} 
ба організації харчування для великої кількості робітників, які займалися заготівлею і доставкою лісу. При цьому, за словами Директора залізниць В. Лисого, останні навідріз відмовлялися працювати за гроші. На думку директора, полегшити ситуацію могла термінова доставка 20 возів з борошном і їх розподіл між робітниками, а також негайне створення при військових командах робітничих відділів з вояків для побудови вузькоколійних залізниць, виділення паровозів і моторів для транспортування дров. В результаті це б зменшило кількість цивільних робітників і зняло б проблему їх продовольчого утримання. Також він повідомив і про те, що існувала можливість співпрацювати з рядом фірм, які б допомогли пришвидшити заготівлю необхідної кількості лісу. В цей час, за підрахунками ДСШ, мінімальна піврічна потреба залізниць у дровах становила 500 тис. м. Про те ці фірми теж висували ряд вимог. Так, фірма “Глезінгер" з Брошнева, повіт Долина потребувала будівництва вузькоколійного полотна до Фельбана протяжністю 15 км, одного моста на Лімницю (100 м) і одного паровозу на 10 тон для транспортування лісу. Зі свого боку вони брали зобов'язання доставити близько 100 тис. м дров. Плата за кожен метр становила 1,5 кг муки. Фірма “Сільвінія” з Вигоди того ж повіту потребувала залізничну лінію на 22 км, 2 паровози на 7 тонн кожен або 20 моторів. Вона б могла доставити 80 тис. м дров. Однак при їх транспортуванні з Людвіківки до Вигоди фірма потребувала допомоги військових бо свого персоналу не цій лінії вистачало. Управа лісів Болехова потребувала на будову колії Тихів-Лушка залізничних матеріалів на 12 км і могла б доставити 40 тис. м дров. Підприємець Касіян з місцевості Одобода-Руігурока потребував 4 км залізничного полотна. Управа лісів Сопів, Яблонів - 30 км, 3 паровози, 60 візків. Підприємці Штериберг і Розенцвайг з Вигнанки потребували теж по 4 км полотна. Граф Дзєдушицький і підприємець Гелер в місцевості Палагичі по 2 і 3 км відповідно. Татарів - 4 км. Ворохта - 5 
км і паровоз. Управа лісів Делятин і Печеніжин по 6 км кожна, Надвірна, Поляніца і Рахів - по 3 км і по одному паровозу на 10 тонн для двох останніх ${ }^{7}$.

Щоб вирішити питання з продовольством, Дирекція залізниць постійно зверталась до Харчового уряду за допомогою. За приблизними підрахунками на 14 березня 1919 р. місячна потреба для прохарчування робітників становила 16 возів збіжжя, 10 вагонів муки (борошна і кукурудзяної), 6 вагонів вівса або ячменю, кілька вагонів картоплі ${ }^{8}$.

Проблеми були і з продовольчим утриманням самих залізничників. 12 березня 1919 р. ДС Внутрішніх Справ повідомив Харчовий Уряд, що він прийняв рішення передати питання забезпечення продовольством залізничників до компетенції Господарського відділу Дирекції залізниць. За австрійських часів їх продовольче утримання прирівнювалося до військовиків, які перебували на фронті і надходило з місцевості, на якій ті перебували. За рішенням Дирекції Державних залізниць Повітовий комісаріат Станіславова скликав усіх повітових комісарів на нараду де вирішено, щоб кожний повіт, за виключенням знищеного Станіславова і повіту Надвірна, забезпечував залізничників усім необхідним самостійно. Для Станіславова і повіту Надвірна Господарський відділ закупив про запас потрібну кількість збіжжя. Тижнева необхідність для них становила 3,5 вагони. Однак окремі повіти такі як Стрий, Самбір, Дрогобич, Тернопіль, Бережани, які також були знищені або вичерпані матеріально вже в ході протистояння з поляками, відмовились харчувати залізничників. Навантаженість на Господарський відділ після цього збільшилась

\footnotetext{
${ }^{7}$ BN, Kolekcija dokumentiw Naukowoho towarystwa imeni T. Szewczenka, MF 92062, Zwit dyrektora zaliznyc $W$. Eysoho pro katastoficzynyj stan na zaliznyci (seredyna bereznia 1919 r.), spamming k.1249-1250.

${ }^{8} \mathrm{BN}$, Kolekcija dokumentiw Naukowoho towarystwa imeni T. Szewczenka, MF 92062, Zwernenja Dyrekcji zaliznyć do Charczowoho uriadu wid 14 bereznia 1919 r. w sprawi dostawky patywa dla zaliznyc, k. 1248.
} 
з 3,5 до 6,5 вагонів і зростала далі. Щоправда трохи рятувало ситуацію те, що зі Жмеринки надійшло 6 вагонів збіжжя, що дозволило тимчасово покрити тижневу потребу. Однак Дирекція залізниць просила Державний Секретаріат допомогти забезпечувати Господарський відділ щотижня 6 вагонами збіжжя9.

Станом на 25 березня 1919 р. за даними Уряду руху в Ходорові лише в цьому повіті проживало 242 залізничники і 348 членів їх сімей. Протягом трьох місяців (січень, лютий і березень 1919 р.) на їхні потреби виділили 222,5 центнерів жита, 185 центнерів пшениці, 503 - муки, 13,5 - хліба, 55 - гречки, 341,6 - буряків і 105 - інших харчів. 3 урахуванням вищесказаного, до кінця липня 1919 р. (про можливу поразку і відступ ніхто тоді ще ніхто не думав - прим. авт.) для прохарчування залізничників Ходорівського повіту за розрахунками Уряду руху необхідно було ще 47520 буханців хліба (для робітників по 2 буханці на тиждень) i 15616 кг муки. Враховувалося, що на виготовлення одного буханця хліба потрібно кілограм муки і це в загальному становило додатково ще близько 8 вагонів збіжжя для покриття усіх потреб. 3 огляду на брак продовольства заборонялися будь-які операції купівлі-продажу або вивозу необхідного збіжжя з повіту. Адже це могло призвести до голоду і інших негативних наслідків ${ }^{10}$.

Окрім вищеперерахованих проблем хаос на залізницях спричиняли окремі самозвані команди станцій, що спекулювали державним і приватним майном. Ускладнювали ситуацію і злодії, що грабували вагони наповнені державним майном, які стояли

\footnotetext{
${ }^{9} \mathrm{BN}$, Kolekcija dokumentiw Naukowoho towarystwa imeni T. Szewczenka, MF 92062, Powidomlennia Dyrekciji Derżawnych Zaliznyc Charczowomu Uriadu pru DSWS wid 12 bereznia 1919 r., 1258-1259.

${ }^{10}$ BN, Kolekcija dokumentiw Naukowoho towarystwa imeni T. Szewczenka, MF 92062, Widpys Powitowoji Charczowoji Uprawy w Chodorowi 25 bereznia 1919 r., k. $1252-1253$.
} 
на залізничних шляхах Львів-Станиславів-Гусятин, Львів-Красне-Броди, Красне-Волочиськ ${ }^{11}$.

Щоб якось полегшити ситуацію і навести лад на залізницях Дмитро Вітовський 10 грудня 1918 р. видав наказ № 68 до окружних військових команд ЗУНР в якому закликав усіх колишніх старшин, підстаршин і вояків австрійської армії, які раніше служили в залізничних чи працювали у робітничих відділах; полонених, які працювали при залізницях як слюсарі, ковалі і т.д.; робітників при телеграфах і телефоністів з'явитися до збірної станиці в Станіславові ${ }^{12}$.

Вже за кілька днів, 13 грудня перші залізничники ЗУНР склали службову присягу, а наступного дня це зробило і керівництво станції Станіславів. Одночасно у залізничному депо відбулись святкові збори робітників у кількості 500 осіб. На цьому зібранні перед учасниками виступили Державний секретар шляхів I. Мирон та О. Устиянович. Підсумком стало рішення призначити на 20 грудня 1918 р. прийняття загальної присяги залізничниками на території Станіславської і Львівської дирекції залізниць ${ }^{13}$.

У січні 1919 р. при ДС військових справ референтом Залізничних справ призначено сотника Юліана Буцманюка ${ }^{14}$. Саме йому Державний Секретаріат доручив створити керівний орган для управління залізничним сполученням, який згодом отримає назву “Залізнодорожна Військова Управа” (ЗВУ). За короткий термін Ю. Буцманюкові вдалося залучити до реорганізації залізничного господарства наступних фахівців: старшин I. Бабія,

${ }^{11}$ Ю. Буцманюк, Залізнодорожна Військова Управа (ЗУВ), [w:] Украйнська Галичька армія. У 40-річчя ії участи у Визвольних Змаганнях в 1918-1920 рр. Матеріяли до історії, red. Д. Микитюк, Вінніпег 1958, t. 1, s. 297.

${ }^{12}$ В. Ортинський, Силові структури, s. 292.

${ }^{13}$ Нове життя, 20 грудня 1918, cz. 20, s. 2.

${ }^{14}$ В. Бемко, Державний секретаріат військових справ, [w:] Украӥнська Галицька армія. У 40-річчя ї участи у Визвольних Змаганнях в 1918-1920 рр. Матеріяли до історіï, red. Д. Микитюк, Вінніпег 1958, t. 1, s. 65. 
В. Лисого, М. Ольшанського, В. Богдановича, В. Гадзінського, К. Мазуренка та ін., які очоливши стаційні команди, встановили належний контроль за переміщенням та вмістом ешелонів ${ }^{15}$.

Важлива подія відбулася 5 січня 1919 р. коли в Станіславові відбулась нарада, на якій вирішили розширити залізничні колії з Підволочиськ в напрямку Тернопіль-Золочів-Красне і так до Львова. Після його звільнення продовжити перебудову у сторону Дрогобича-Самбора. Це повинно було полегшити транспортування військового майна, продовольства і вояків з Наддніпрянщини. Перша перебудова мала відбутися на лінії Красне-Броди ${ }^{16}$.Вже через кілька днів, 16 січня на “Перешивку вузькоколійних рейкових шляхів Галичини” виділено 5 млн грн, а постановою Ради Міністрів УНР 22 лютого ще 10 млн $^{17}$.

Уряд ЗУНР постійно дбав про матеріальне становище залізничників. 26 січня 1919 р. розпорядженням Державного Секретаріату введено одноразову грошову премію для урядовців та залізничників, які від 1 грудня 1918 р. перебували на відповідній службі. Її планували виділити в перших днях лютого у розмірі одноразової компенсації, яку раніше виплачував австрійський уряд ${ }^{18}$. Асигновувалися кошти і на оновлення рухомого складу та заготівлю необхідних паливно-мастильних матеріалів. Так, на початку січня 1919 р. на потреби залізниці виділили 60 млн грн ${ }^{19}$. Вже 28 лютого для експлуатації залізниць, заготівлі пали-

\footnotetext{
${ }^{15}$ Д. Футулуйчук, Участь жандармерії в державному будівниитві та захисті суверенітету ЗУНР, [w:] дис... канд.іст.наук: 20.02.22, Львів 2004, s. 143.

${ }^{16}$ Centralnyj Derżawnyj Archiw Wyszczych Organiw Wlady [dalej: CDAWOW], Kyjiw, fond 2188, op. 1, poz. 18, Operatywni donesennia wijskowych grup ta rozporiadżenja Naczalnoji Komandy pro roztaszuwannia wijsk i chid wojennych dij, k. 109.

${ }^{17}$ Р. Тимченко, Воєнно-політичне й економічне співробітниитво УНР $і$ ЗОУНР в першій половині 1919 р., “Український історичний збірник”, Київ 13/2010, s. 204.

${ }^{18}$ Нове життя, 30 січня 1919, cz. 22, s. 2.

${ }^{19}$ Там же cz. 21, s. 1.
} 
ва і металу Держсекретаріату шляхів Галичини виділили ще 17 млн грн ${ }^{20}$.

Безпосередньо за практичну діяльність залізниць на території Галичини відповідав залізнодорожний курінь, який сформували у Стрию, а згодом перевели до Станіславова. Командантом залізнодорожного куреня був отаман Всеволод Богданович, заступник - сотник Володимир Гадзінський і ад'ютант - поручник Антін Галька. До складу куреня увійшли 4 сотні і майстерня обладнана різними технічними верстатами. Після завершення Першої світової війни у лавах куреня залишилась частина іноземців, які погодились продовжити службу у лавах Галицької армії (ГА). Командантом куреня став сотник Леопольд Райтер, а його заступником - поручник Ярослав Глібовицький ${ }^{21}$. На жаль, не вдалось встановити коли курінь був реорганізований у “Залізно-дорожнє Депо”. Проте відомо, що в ході травневого відступу 1919 р. його місцем дислокації стала станція Вигнанка під Чортковом. В цей час декілька залізничників-іноземців відмовились продовжувати службу в ГА мотивуючи це відсутністю перспективи у веденні подальшої боротьби з поляками або бажанням побачити рідню, яку залишили ще в ході світової війни. В цей час Депо надалі продовжив очолювати сотник Л. Райтер, йому допомагали поручник-інженер Я. Глібовицький, четар Данило Монджейовський з команди Залізно-дорожньої Управи. Серед підстаршин залишилося декілька німців ${ }^{22}$.

В той час коли окремі старшини залишали службу в ГА інші намагались всіляко її підтримувати і допомагати. Наприклад, єврейські залізничники після проведених у Станіславі зборів, вирішили створити організацію яка б допомагала українцям утри-

${ }^{20}$ М. Литвин, К. Науменко, Історія ЗУНР, Львів 1995, s. 136.

21 Л. Шанковський, Украӥнська Галищьька армія, Львів 2010, s. 301-302.

22 Д. Монджейовський, Залізно-дорожне Депо У.Г.А., “Літопис Червоної Калини", Львів 12/1938, s. 18. 
мувати порядок на залізницях Галичини ${ }^{23}$. У травні 1919 р. у Заліщиках на контрактній основі до лав залізно-дорожньої служби вдалось залучити декілька підстаршин-залізничників з Австрії ${ }^{24}$. Вже 15 червня 1919 р. відбулись кадрові зміни - референтом Залізнодорожного Депо призначили сотника Сакса ${ }^{25}$. Наказом ч. 31 від 19 червня 1919 р. всі старшини, підстаршини і вояки, які в колишній австрійській армії служили у залізно-дорожному полку і не були потрібні на фронті мали прибути до залізно-дорожнього куреня в Чорткові для проходження подальшої служби. ${ }^{26}$

Внаслідок відступу Галицької армії у середині липня 1919 р. Депо на 8 возах перевезло своє майно через 3бруч ${ }^{27}$. На Наддніпрянщині, як і в Галичині проблема нестачі кадрів і організації залізничної служби залишилася актуальною. У статті “Галицькі залізничники" є відомості про те, що через Збруч вдалось евакуювати понад 1115 залізничників. Більшість з них опинилися у Кам’янці Подільському. Через брак житлової площі у місті, їх тимчасово розмістили на залізничному вокзалі. Тут для їхніх потреб одразу відкрили польову кухню. Невдовзі усім евакуйованим залізничникам виплатили належну платню, яку ті не отримували ще від часу перебування в Галичині. Додатково усім евакуйованим залізничникам Міністерство Галицьких справ тричі виділяло допомогу по 300 грн, а одного разу - 600 грн. Для найбільш потребуючих Міністерство надало ще й 300 аршинів полотна для виготовлення сорочок, а на потреби польової кухні

\footnotetext{
${ }^{23}$ Народ, 15 травня 1919, cz. 24, s. 4.

${ }^{24}$ CDAWOW, fond 2192, op. 1, poz. 2, Lystuwannia z NKHA, nakazy po Armii pro wydilennia kosztiw dla potreb Armiji, pryznaczennia na slużbu, wijskowu mobilizaciju starszyn, widnoszennia wijska do cywilnoho naselennia, wijskowi dii w Armii ta in., k. 101.

${ }^{25}$ CDAWOW, fond 2192, op. 1, poz. 1, Nakaz wid 15 czerwnia 1919 r. pro orhanizaciju Operatywnoho sztabu, k. 276.

${ }^{26} \mathrm{BN}$, Kolekcija dokumentiw Naukowoho towarystwa imeni T. Szewczenka, MF 87300, Nakaz NKHA cz. 31 wid 19 czerwnia 1919 r., k.56.

27 Д. Монджейовський, Залізнодорожне Депо, s. 18.
} 
3,5 пуди цукру. Окрім того передбачалось виплачувати додаткову одноразову допомогу у випадку надзвичайної скрути. Загалом на початок серпня 1919 р. на потреби залізничників Міністерство виділило 1672000 грн, а 1 серпня усіх їх прийнято на службу відповідно до фаху ${ }^{28}$.

Вже у наступному номері газети “Галицький Голос" подана дещо інша інформація про кількість залізничників, що прибули з Галичини на Наддніпрянщину, та суму коштів асигнованих на їхні потреби. Так, за новими даними, у липні 1919 р. вдалось евакуювати 1300 осіб, з яких близько 150 осіб були розміщені на залізничній станції Проскурів та 650 осіб - в Жмеринці. Окрім виділених 1,6 млн грн, видано 1,3 тис. аршинів полотна. На квоту у 30 тис. грн вдалось відкрити одну кухню для персоналу в Проскурові, на 50 тис. грн ще одну в Жмеринка, а третю у Кам' янці Подільському - за 70 тис. грн. Для залізничників в Дунаївцях і Ярмолинцях, зважаючи на відсутність там польових кухонь, видали окрему допомогу. Вживались заходи щодо закупівлі шкіри і полотна, для пошиття необхідного одягу та взуття ${ }^{29}$.

За рішенням уряду УНР галицькі залізничники переходили на тимчасову службу на придніпрянські залізниці займаючи ті ж посади, що до того і в Галичині. При цьому галичанам одразу ж наданий перший кваліфікаційний ступінь придніпрянських розрядів. Це зрівняння стосувалось і платні, що нараховувалась відповідно до зайнятих посад з урахуванням добового та інших додаткових надбавок без відрахувань на випадок хвороби. Галицькі залізничники отримували повне придніпрянське обмундирування. Для купівлі предметів щоденного вжитку уряд УНР виділяв одноразову допомогу у розмірі 3 тис. грн. Галичани могли стати членами будь яких придніпрянських залізничних кооперативів $і$ продовольчих артілей на рівних правах з наддніпрянцями. Звіль-

\footnotetext{
${ }^{28}$ Галицький Голос, 16 серпня 1919, cz. 1, s. 4.

${ }^{29}$ Там же, 4 вересня 1919, cz. 3, s. 3.
} 
нення із займаної посади могло відбутись лише після рішення винесеного дисциплінарним судом, що складався 36 членів, а також 22 делегатів професійної організації, вибраних 3-поміж галицьких залізничників тієї категорії, до якої належав претендент на звільнення та одного делегата від залізничної інспектури ${ }^{30}$.

На Наддніпрянщині залізниці підпорядковувались Міністерству Шляхів, Міністерству Військових справ та його підвідділу - "Військових комунікацій”. Через те, що їхні дії вносили хаос на залізниці, залізничники вирішили внести в Раду Народних Міністрів проект "Про передачу справ пересування військ та військових вантажів виключно до Міністерств Шляхів" "31. На жаль, не вдалось виявити матеріали, які б підтвердили або спростували виконання цього розпорядження.

За Збручем Залізнодорожне Депо ГА організувало два вишколи для поповнення персоналу залізничної служби. На початку липня 1919 р. у ньому служили 3 старшини, 12 підстаршин та 45 вояків ${ }^{32}$. Вже 26 вересня 1919 р. Депо перебазувалося до Жмеринка, де у його майстернях вдалось збудувати один потяг, відремонтувати три менш пошкоджені паротяги, один бронепотяг і декілька мостів ${ }^{33}$. Місцями дислокації Депо в різні часи стали станції у Кам'янці та Могилеві. Галицькі залізничники усюди організовували збір залізничного майна, ремонт локомотивів й бронепотягів. Для пересування Депо мало власний потяг, що складався з локомотиву й 11 вагонів. Машиністи потягу й обслуга була своя. Депо перестало існувати в епоху Червоної Української Галицької Армїі ${ }^{34}$.

\footnotetext{
${ }^{30}$ Там же, 16 серпня 1919, cz. 1, s. 3.

31 Там же, 29 вересня 1919, сz. 5, s. 1.

32 Л. Шанковський, Українська Галищька армія, s. 301.

33 Д. Монджейовський, Залізнодорожне Депо, s. 18.

34 Л. Шанковський, Українська Галииьька армія, s. 301.
} 
Поряд 3 Депо діяла "Залізнодорожна військова управа" (ЗВУ), яку створили розпорядком ч. 20 від 2 лютого 1919 р. Ї̈̈ завдання полягало у встановлені контролю за пересуванням цивільних і військових транспортів та діяльності військових команд станцій ${ }^{35}$. Для виконання цього розпорядження створили 5 Команд контролю шляхів (КОШТ) у Тернополі, Ходорові, Станіславові, Чорткові, Стрию та станцій (КОД) $)^{36}$. КОШТ очолив сотник Ю. Буцманюк, КОД - поручник Кость Мазуренко ${ }^{37}$. До обов'язків КОШТу входило: виконання всіх завдань ЗДВУ; нагляд над командами залізничних станцій у своєму районі; висилка, прийом і облік усіх військових транспортів; організація заснована лізничної жандармерії; охорона залізничних шляхів і всіх розташованих на них об’єктів. Без відома КОШТу жоден транспорт згідно із розпорядженням не міг від'їхати.

Команду станцій очолювали військові коменданти до обов'язків яких належало: виконання всіх завдань ЗВУ і КОШТу; охорона державного майна, спокою та порядку на станціях; підтримання залізничної влади; нагляд за своєчасною подачею замовлених вагонів для відправлення транспортів, та пришвидшення їх відправки. КОД не мав права затримувати відправку транспортів, але здійснював контроль за кількістю переїжджаючих потягів, старшин і вояків в них.

Команді Двірця також підпорядковувались усі існуючі на залізничних станціях харчові і санітарні станиці та відділи залізничної охорони. Для полегшення контролю на залізницях кожний військовий транспорт, що прямував на фронт або в запілля нумерувався ${ }^{38}$.

\footnotetext{
${ }_{35}^{35}$ В. Бемко, Державний секретаріат, s. 68.

${ }^{36}$ Ю. Буцманюк, Залізнодорожна Військова Управа, s. 298.

37 Л. Шанковський, Украӥнська Галищька армія, s. 301.

${ }^{38}$ Ю. Буцманюк, Залізнодорожна Військова Управа, s. 300-302.
} 
В ЗВУ в різні часи працювали поручники Михайло Шумейко і Роман Свищун, четарі Яким Бубнюк, Іван Кекіш, Ілько Когут, Дмитро Кравець, Степан Курій, Данило Моджейовський, Степан Придун, Володимир Смольницький ${ }^{39}$.

В ході Чортківської наступальної операції НКГА наказом ч. 71 від 26 червня 1919 р. провела реорганізацію Залізно-дорожної служби. Так Залізнодорожна військова Управа стала безпосередньо підпорядковуватись Начальнику Оперативного відділу при НКГА. До сфери її діяльності належало забезпечення функціонування залізниць, будівництво нових шляхів, зберігання залізничного майна, слідкувати за транспортуванням війська і майна. ЗВУ підпорядковувалися всі військові залізно-дорожні частини, контролі шляхів і транспортів, команди залізничних станцій, залізнодорожна охорона.

Встановлено 2 контролі шляхів і транспортів 3 центрами у Тернополі (КОШТ I) і в Чорткові (КОШТ II). До КОШТу І входили залізниці на лінії Тернопіль-Підволочиськ, Тернопіль-Збараж, Тернопіль-Березовиці-Остров-Теребовля, Тернопіль-Березовиця-Підгайці-Бережани, Тернопіль-Красне. Кошт II об’ єднував лінії Нижнів-Гусятин, Білочортківська-Заліщики, Вигнанка-Івана Пусте.

До обов'язків Кошту входило виконання усіх наказів ЗВУ, нагляд за Командами станцій у своїх районах, керування рухом залізничних ешелонів, охорона майна і організація залізнодорожної жандармерії, охорона залізничних шляхів і усіх розміщених на них об'єктах, виконання наказів НКГА по організації залізничного руху ${ }^{40}$.

3 переходом Галицької армії на Наддніпрянщину відбулись кадрові зміни у керівництві ЗВУ. Наприкінці липня 1919 р. замість

39 Л. Шанковський, Українська Галицька армія, s. 301-302.

${ }^{40} \mathrm{BN}$, Kolekcija dokumentiw Naukowoho towarystwa imeni T. Szewczenka, MFm 87300, Nakaz wijskam cz. 71 wid 26 czerwnia 1919 r., k. 99. 
Ю. Буцманюка Управу очолив сотник Матвій Яворський ${ }^{41}$. В ході наступу на Київ у серпні цього ж року ЗВУ переїхала до Кам’янця Подільського, а звідти перебралася до Жмеринки. Загальна чисельність залізничників в цей час у місті сягала 4 тис. осіб ${ }^{42}$. “Справжньою Божою карою ставали всякі “начальнікі постачання”, “полковнікі” зі спецдорученням, отамани фіктивних загонів, коменданти неіснуючих дивізій та інші достойники, які у настирливій формі жадали паровиків, “екстрених вагончиків”, під загрозою револьверів забирали від обслуги паровоз чи “вагончик"”,43 - саме в таких умовах, як згадував Ю. Буцманюк, галичанам доводилось провадити залізничну службу на Наддніпрянщині.

3 метою нормалізації становища на залізницях Наддніпрянщини 27 серпня 1919 р. НКГА вирішила створити спільний $з$ наддніпрянцями колегіальний орган, що відповідав за безперебійне транспортування залізничних потягів - Центральну Залізнодорожну військову управу (ЦЗВУ). До неї увійшли представники, як Галицької армії, так і армії УНР44. Управа планувала створити шість Контролів Шляху серед яких ч. 1 - Жмеринка, ч. 2 - Козятин, а в міру подальшого просування армії у напрямку на Київ-Одеса ч. 3 - Київ, ч. 4 - Бобрянськая, ч. 5 - Одеса, ч. 6 - Проскурів. Тільки КОШТ міг розпоряджатися вагонами і паровозами у підконтрольному окрузі. Етапні команди обох Армій в порозумінні з ЦЗВУ повинні були відкрити “Харчові станції”. Такі станції першими мали з'явитися в окрузі контролю ч. 2 - Козятин. Для загального перевозу військ і охорони шляхів ЦЗВУ тимчасово утворювала три райони пересування військ: Козятинський в межах п’яти залізничних шляхів від Козятина

\footnotetext{
${ }^{41}$ В. Ортинський, Силові структури, s. 295.

${ }^{42}$ Ю. Буцманюк, Залізнодорожна Військова Управа, s. 303.

${ }^{43}$ Д. Футулуйчук, Участь жандармеріï, s. 148.

${ }^{44}$ Centralnyj Derżawnyj Istorycznyj Archiw Ukrainy [dalej: CDIAU], Lwów, kol. 9, MF 87300, Nakaz wijskam cz. 128 wid 27 serpnia 1919 r., k. 171.
} 
до станції Брацлав, Шепетівка, Коростень, Фастів, Христинівка. Відповідальним за організацію - поручник Квасницький. Проскурівський три залізничні шляхи від Проскурова до Кам'янця-Подільського, Волочиська, Чотирбоки. Жмеринський три залізничні шляхи від Жмеринки до станції Могилів Подільський, Вапнярка, Богутівці. Відповідальний - сотник Гречіна. До Козятинського і Жмеринського районів приділялися Галицькі кошти ${ }^{45}$.

Наказом ч. 131 від 7 вересня 1919 р. вирішено, що транспорт, який перебував в області оперуючої Армії мав бути розвантажений не довше як за 12 год. Товарні потяги, які з огляду на оперативну ситуацію не могли потрапити до потрібного місця не повинні були затримуватись довше, як на три дні. Транспорти 3 військами на 24 год.

Одночасно ЦЗВУ отримала нове завдання - організація доставки пошти. Для пришвидшення роботи польових пошт і Етапних поштових урядів, які знаходилися при Командах планувалося відкрити 4 тимчасові Рухомі польові сортівні, які курсували б потягами на лініях Кам'янець Подільський-Жмеринка (рухома Польова сортівня ч. 1), Жмеринка-Київ (ч. 2), Жмеринка-Коростень (ч. 3), Жмеринка-Вапнярка (ч. 4). Для потреб рухомих сортівень в потягах виділяли по 2 вагони. 3 метою збільшення кількості професійного поштового персоналу Команда Етапу армії (КЕА) планувала вислати 10 підстаршин до Поштової дирекції при етапі для завершення поштових курсів ${ }^{46}$.

3 наближенням осені у Галицькій армії розпочав стрімко поширюватись тиф. Станом на 5 вересня 1919 р. особовий склад залізнодорожніх військ на 50 \% був хворим. Для заміни хворих командування пропонувало взяти як поповнення 1116 залізнич-

\footnotetext{
${ }^{45}$ BN, Kolekcija dokumentiw Naukowoho towarystwa imeni T. Szewczenka, MF 87300, Nakaz wijskam cz. 128 wid 27 serpnia 1919 r., k. 171.

${ }^{46}$ BN, Kolekcija dokumentiw Naukowoho towarystwa imeni T. Szewczenka, MF 87300, Nakaz wijskam cz. 131 wid 7 weresnia 1919 r., Kyjw k. 179.
} 
них урядовців віком від 18 до 28 років 3 "Галицької Дирекції залізниць”, що входила до складу Міністерства шляхів УНР ${ }^{47}$. Однак через брак архівних матеріалів не відомо чи вдалось реалізувати ці плани.

20 жовтня 1919 р. Начальна Інтендатура ГА видало розпорядження ч. 4 про встановлення заробітної плати залізничникам при $3 \mathrm{BY}^{48}$.

\begin{tabular}{|c|c|l|l|l|}
\hline \multirow{2}{*}{ Номер } & Степень & \multicolumn{1}{|c|}{ Цивільний службовий характер } & \multicolumn{2}{|c|}{$\begin{array}{c}\text { Денний } \\
\text { додаток }\end{array}$} \\
\cline { 4 - 6 } & & & Грн & шаги \\
\hline 1 & $\mathrm{~V}$ & Старший радник, ст. інспектор & 65 & \\
\hline 2 & VI & Радник, інспектор & 60 & \\
\hline 3 & VII & $\begin{array}{l}\text { Ст. комісар, ст. комісар будови, ст. } \\
\text { комісар машиновий, ст. комісар мір- } \\
\text { ництва, ст. ревідент, ст. офіціял }\end{array}$ & 55 & \\
\hline 4 & VIII & $\begin{array}{l}\text { Комісар, комісар будови зг. машин, } \\
\text { комісар мірництва, ревідент, офіці- } \\
\text { ял }\end{array}$ & 50 & \\
\hline 5 & IX & $\begin{array}{l}\text { Концепіста, адюнкт будови зг. ма- } \\
\text { шин, адюнкт мірництва, адюнкт }\end{array}$ & 45 & \\
\hline 6 & $\mathrm{X}$ & $\begin{array}{l}\text { Конціпснт, асистент будови зг. ма- } \\
\text { шин, асистент мірництва, асистент } \\
\text { конципіст, асистент }\end{array}$ & 40 & \\
\hline 7 & & Аспірант & 30 & \\
\hline 8 & & Вольонтар & 25 & \\
\hline
\end{tabular}

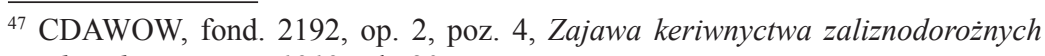
wijsk wid 5 weresnia 1919 r., k. 307.

${ }^{48}$ BN, Kolekcija dokumentiw Naukowoho towarystwa imeni T. Szewczenka, MF 87300, Zahalne rozporiadżenia NIHA cz. 4 wid 20 żowtnia 1919 r., k. 222. 


\begin{tabular}{|c|c|c|c|c|}
\hline \multirow[t]{2}{*}{ Номер } & \multirow[t]{2}{*}{ Степень } & \multirow[t]{2}{*}{ Цивільний службовий характер } & \multicolumn{2}{|c|}{$\begin{array}{l}\text { Денний } \\
\text { додаток }\end{array}$} \\
\hline & & & Грн & шаги \\
\hline 9 & Підурядники & $\begin{array}{l}\text { Завідник майстерні в головних, на- } \\
\text { правчих і сигналових майстернях, } \\
\text { як і електричних заведеннях, ма- } \\
\text { шинові майстри, конц. експедієнти, } \\
\text { паровізники, корабельні і звичайні } \\
\text { машиністи, стаційні і возові майс- } \\
\text { три, возові ревізори, провідник май- } \\
\text { стерні (верифірер), ревізори поїздів, } \\
\text { щляхові, мостові, будівельні і сигна- } \\
\text { лові майстри, веркмайстри в імпрег- } \\
\text { наційних заведеннях і в заведеннях } \\
\text { світла, майстри від світла, магази- } \\
\text { нери, старші кондуктори, майстер } \\
\text { перетоковий }\end{array}$ & 20 & \\
\hline 10 & Служба & $\begin{array}{l}\text { Наглядач освітлення, мостовий слю- } \\
\text { сар, помічник паровізника, доглядач } \\
\text { машин, ст. топник, ст. верховий, } \\
\text { наглядач помп, сигналовий слюсар, } \\
\text { наглядач перетоку возів, наглядник } \\
\text { возів, слуга бльокових сигналів, } \\
\text { кондуктори, топники паровозів, мо- } \\
\text { торовий, старший перетоковий, топ- } \\
\text { ник, провірники збічниць та ін. }\end{array}$ & 15 & \\
\hline
\end{tabular}

Повноцінне функціонування ЗВУ напряму залежало від діяльності залізничної жандармерії, наказ про створення якої вийшов 24 березня 1919 p. ${ }^{49}$. До ii завдань входили: перевірка документів у тих військових і цивільних, які користувались залізницею; виявлення й затримання осіб, підозрюваних у злочинах, шпигунстві, провокаціях і диверсіях; забезпечення правопорядку в потягах, охорона важливих кур'єрів та майна. Службовці залізничної жандармерії відповідно до наказу отримали ті ж права, що й Державна польова жандармерія. Наказ регулював i

${ }^{49}$ CDIAU, fond 581, op. 1, poz. 146, Dennyj nakaz cz. 99 wid 9 kwitnia 1919 r. “Wytiah iz rozporiadku DSWS cz. 5629 wid 24 bereznia 1919 r.”, k. 20. 
умови арешту, і затримання працівників залізниці, які слід було обов' язково узгоджувати з керівництвом. Залізнична жандармерія адміністративно підпорядковувалася військовому відомству, в питаннях несення служби - Залізничній військовій управі, на місцях дислокації- коменданту станції ${ }^{50}$. Щодо обмундирування то воно було таким ж, як і у Державної чи Польової жандармерії. Лише на лівому рукаві мундиру розміщувалась синя опояска 3 літерами "ЗЖ”.

Задля підвищення ефективності залізничної жандармерії 6 травня 1919 р. видано розпорядження про створення спеціальних відділів в 14 містах: Станіслав, Ходорів, Тернопіль, Стрий, Самбір, Чортків, Коломия, Красне, Броди, Підволочиськ, Гусятин, Лавочне, Ворохта, Бережани. До їх складу входило по 8-20 осіб, на які покладалось завдання перевіряти усіх залізничників, зберігати неушкодженими потяги з рухомим складом та державним майном, що перевозилось у них ${ }^{51}$. Ухвалення закону перш за все зумовлене початком травневого відступу Галицької армії в район Заліщиків.

Таким чином, можна зробити висновок, що галичанам вдалось створити досить добре організовану залізничну службу, яка незважаючи на суттєві проблеми в функціонуванні здійснювала своєчасне транспортування майна, бойової техніки і живої сили. Задля збереження на ній спокою створено залізничну жандармерію.

\section{Бронепотяги Галицької армії}

Початок українсько-польської війни наочно продемонстрував, що швидкість і маневреність бойових підрозділів відігравали ключову роль в ході військового протистояння. Забезпечити таку перевагу мали бронепотяги, якими користувались як українці так

${ }_{50}$ В. Ортинський, Силові структури, s. 295.

${ }^{51}$ I. Боберський, Щоденник, 1918-1919 pp., red.: Ю. Мицик, Київ 2003, s. 223. 
і поляки. Однак через міжнародну ізоляцію українці могли будувати броньовики здебільшого найпримітивніших конструкцій або захоплювати їх у ворога.

Бронепотяги ГА, як правило, формувалися на основі звичайного залізничного ешелону, що складався з кількох платформ та вагонів. На ньому встановлювали одну-дві гармати, декілька кулеметів й така “імпровізована панцирка", як тоді казали, вирушала в бій. 3 часом платформи стали зміцнювати дубовими балками, а потім будували на них своєрідні “броньовані будки”. Паротяг та вагони обкладали листами товстої бляхи. Згодом на озброєння Галицької армії надійшло декілька справжніх бронепотягів, які вдалось збудувати на заводах Дрогобича ${ }^{52}$.

Інженер Крифонівський у спогадах залишив свідчення про будівництво галичанами трьох бронепотягів. Їх будували нашвидкоруч, за досить простою конструкцією з наявних залізничних платформ, пасажирських і товарних вагонів. За його словами, перші два потяги, зібрані у залізничних майстернях Самбора, вже 5-15 грудня 1918 р. здійснювали бойове чергування на колії Самбір-Львів. Третій бронепотяг сформували у Стрию ${ }^{53}$.

Перший бронепотяг українського виробництва під керівництвом О. Бережницького, як вже згадувалось раніше, з'явився 3 листопада 1918 р. у Самборі ${ }^{54}$. Його ж призначили комендантом, I. Садлича - заступником, за сумісництвом комендантом кулемета і амуніції. Залога потяга складалась 318 вояків, 12 рушниць, кулемету і 60 гранат. Харчовий блок очолив четар Карло Коберський. Згодом потяг був озброєний ще однією 8 дм гарматою, яку привіз четар Асцельмаєр з Чернівців. Кількість кулеметів збільшилась

\footnotetext{
52 П. Ткачук, Сухопутні війська Збройних сил України доби револючії 1917 1921 рр., Львів 2009, s. 201.

53 Я. Тинченко, Панциині потяги, панцерники та залізничні війська у Визвольній війні 1917-1920 рр.: науково-популярне видання, Київ 2012, s. 96.

54 І. Садлич, На паничири̧і під Хировом, «Літопис Червоної Калини», Львів 6/1939, s. 2.
} 
до семи. Наприкінці листопада 1918 р. команда потягу складалася 33 старшин, 5 підстаршин, 64 вояків, 2 машиністів, 54 рушниць та 7 кулеметів.

Після здобуття Хирова потрібен був інший бронепотяг. НКГА вислала до Дрогобича бунчужного Кульчицького, щоб той виготовив в міському депо інший бронепотяг. Невдовзі бунчужний разом з новеньким бронепотягом прибув назад до Хирова. На його озброєнні вже були дві гармати і два броньовані вагони. Командування взяв на себе четар I. Садлич, разом з бунчужним Кульчицьким ${ }^{55}$.

У смузі бойових дій I Галицького Корпусу (ГК) полковника Осипа Микитки опинилася залізниця Рава-Руська-Белз-Кристинопіль, зв' язана з лінією Львів-Стоянів. Тут оперував бронепотяг під назвою “Поїзд Ч. 212”, базою для якого стало м. Радехів. Його збудував чех Батек. У стиках передньої та бічних стін вагону, в якому перевозили вугілля, обкладених дев'ятиміліметровою бляхою, він зробив отвори і встановив дві 75-мм гармати. Наступний вагон був укріпленений бляхою тільки з боків і мав два важкі кулемети. У ньому ж були зроблені амбразури для ведення рушничного вогню. Бойову частину ешелону завершував захищений такою ж бляхою паротяг. Команда бронепотяга складалася 3 12 осіб на чолі з командиром-хорунжим. Через брак залізничників-українців машиніст за національністю був поляком.

Цей бронепотяг особливо відзначився в боях за Белз, Сокаль і Раву-Руську. Під час бою за Кристинопіль у січні 1919 р. виявлено значний недолік у його конструкції, а саме у способі розміщення гармат. Через недостатній кут обстрілу зменшувалися його бойові можливості. Тому, комендант потягу прийняв рішення

\footnotetext{
55 Там же, s. 2-3; М. Моргун, Броньовані частини Галицької армії та їх участь в украӥнсько-польській війні 1918-1919 рр., [w:] Воєнна історія Галичини та Закарпаття: матеріали Всеукр. наук. військ.-іст. конф. (Львів, 15 квітня 2010 р.), Львів 2010, s. 247.
} 
повернути бронепотяг до Радехова для перебудови ${ }^{56}$. Після модернізації бойову міць становили одна 80-мм польова гармата, дві піхотні гармати і три кулемети. Залога-один старшина і 23 вояки ${ }^{57}$. “Поїзд Ч. 212” також отримав і машиніста-українця. Вже у травні 1919 р. цей бронепотяг було розформовано ${ }^{58}$.

Бойові дії ІІ ГК полковника М. Тарнавського підтримував панцерний потяг “Ч. 1”, що діяв на магістралі Львів-Ходорів. Його збудували на станції Старе Село за ініціативою командира артилерійської батареї поручника-буковинця Володимира Тотуєскула, що вирішив розмістити свої гармати на двох залізничних платформах. Сюди ж додали декілька кулеметів. До “імпровізованого панцерника” причепили ще один вагон, де розміщувалась чета вояків. У першому ж бою за Сихів було смертельно поранено команданта В. Тотуєскуля"59. Згодом бронепотяг “Ч. 1” модернізували так, що перед паротягом залишили лише одну платформу, на якій встановили своєрідну “броньовану будку” з гарматою i кулеметами. Керування бронепотягом, якого включили до складу II Коломийської бригади, перебрав на себе поручник Стефан Руменович ${ }^{60}$. Подальша доля панцерного потягу “Ч. 1” не відома.

\footnotetext{
${ }^{56}$ О. Дедик, Війна на залізничних коліях. Панцерники УГА, “Літопис Червоної Калини”, Львів 6-7/1992 ; П. Ткачук, Сухопутні війська, s. 202 ; С. Печенюк, Бронепотяги - фортеиі на рейках, "Технічні досягнення минулого”, Київ 12/2010, s. 32-33.

${ }^{57}$ М. Моргун, Броньовані частини, s. 248.

${ }^{58}$ О. Дєдик, Війна на залізничних коліях ; П. Ткачук, Сухопутні війська, s. 202.

${ }^{59}$ C. Печенюк, Бронепотяги - фортеці на рейках, s. 33.

${ }^{60}$ I. Карпинець, Історія 8-ої Галищької бригади, “Літопис Червоної Калини” 7-8/1934, s. 28 ; О. Дедик, Гонитва за мостами: боротьба за переправи через Дністер під час українсько-польської війни 1918-1919 років, “Цитаделя. Львівський мілітарний альманах", Львів 2/2010, s. 33 ; О. Дєдик, Війна на залізничних коліях ; П. Ткачук, Сухопутні війська, s. 202 ; Д. М. Короткі історичні нариси бригад УГА [w:] Украӥнська Галищька армія. У 40-річчя ї̈ участи у Визвольних Змаганнях в 1918-1920 рр. Матеріяли до історії, red.: Д. Микитюк, Вінніпег 1958, t. 1, s. 88.
} 
Наприкінці грудня 1918 р. під керівництвом М. Солодухи в Дрогобичі збудовано “імпровізований” бронепотяг, що складався з броньованого паровозу, двох пасажирських вагонів і трьох платформ. На озброєні була гармата і 3 кулемети. В березні 1919 p. в Дрогобичі вдалось збудувати ще один бронепотяг з більш надійною і сучасною конструкцією, на озброєнні - гармата і 7 кулеметів ${ }^{61}$.

Є відомості про російський бронепотяг, що стояв на станції Слобода Теофілівка. Саме його майор Пап просив у ОВК Стрий 8 січня 1919 р. Він хотів переозброїти цей бронепотяг і замінити на ньому колеса на ті, які використовувались на галицьких залізницях ${ }^{62}$.

Станом на 14 січня 1919 р. у ГА було три панцерні потяги при групах отамана Микитки, полковника Павленка і Південній ${ }^{63}$. За твердженням польського історика М. Кротофіла, 10 березня 1919 р. їх було лише два і вони підпорядковувались штабу армії ${ }^{64}$. За іншими даними ці бронепотяги входили до складу III $\Gamma^{65}$. Цю думку підтримує інший польський історик М. Клімецкі. Він стверджує, що ці бронепотяги патрулювали колії Львів-Стрий та Ходорів-Самбір й належали до II і III Галицьких корпусів. Їх озброєння складалося з однієї-двох гармат і кількох кулеметів ${ }^{66}$. Також є відомості про бронепотяг, що входив до складу групи

${ }^{61}$ M. Krotofil, Ukraińska Armia Halicka 1918-1920. Organizacja,uzbrojenie, wyposażenie $i$ wartość bojowa sit zbrojnych Zachodnio-Ukraińskiej Republiki Ludowej, Toruń 2002, s. 85.

${ }^{62}$ CDAWOW, fond 2188, op. 1, poz. 15, Zwernenia majora Papa do Obl. Komandy Stryj wid 8 sicznia 1919 r., k. 55.

${ }^{63}$ CDAWOW, fond 2188, op. 1, poz.19, Zwit pro stan czyselnist Halyckoi Armii wid 14 sicznia 1919 r., k. 8

${ }^{64}$ M. Krotofil, Ukraińska Armia Halicka, s. 85.

${ }^{65}$ CDAWOW, fond. 2188, op. 1, poz. 15, Zwit pro stan III korpusu Halyckoji Armiji wid 10 bereznia 1919 r., k. 2.

${ }^{66}$ M. Klimecki, Polsko-ukraińska wojna o Lwów I Galicję Wschodnia 1918-1919, Warszawa 2000, s. 150-197. 
“Глибока". Його залога становила 2 старшин, 10 підстаршин, 35 вояків, гармата 80 мм, 5 кулеметів Максима і один Льюїс ${ }^{67}$. Вже 15 квітня бронепотягів було чотири (по одному у I та II Галицьких корпусах і два у III корпусі); 15 травня також чотири (при штабі армії, по одному у 4 Золочівські, 7 Львівській і 8 Самбірській бригадах $)^{68}$. Поляки в цей час володіли десятьма такими броньованими потягами ${ }^{69}$. У літературі фігурують наступні назви"Piłsudczyk", "Pionier", “Odsiecz I", “Odsiecz II", "śmiały", "PP 3”, "Gromobój”, "Smok" 70. За іншими даними поляки використовували 3-4 бронепотяги на лінії Рава-Руська-Белз, 5-6 потягів на лінії Перемишль-Белз, 2-3 потяги на лінії Перемишль-Хирів ${ }^{71}$.

В квітні 1919 р. один бронепотяг НКГА приділила до 5 Сокальської бригади. Його команда - старшина і 23 вояки; на оснащені - 80-мм гармата, дві піхотні гармати і три кулемети. Бронепотяг, що входив до складу 2-ї Коломийської бригади мав на оснащені гармату і чотири кулемети. Команда - старшина і 30 вояків. До 7-ї Стрийської бригади входив один не броньований потяг, оснащений гарматою і двома кулеметами. У 8-й бригаді бронепотяг з 80-мм гарматою і 6 кулеметами. Команда - 3 старшин і 64 вояки ${ }^{72}$.

Багатою на події є історія бронепотягу “Ч. 2". Його створив четар М. Солодуха у майстерні “Галіція" в Дрогобичі ${ }^{73}$. До

\footnotetext{
${ }^{67}$ CDAWOW, fond 2188, op. 1, poz. 15, Zwit pro stan III korpusu Halyckoi Armii wid 9 bereznia 1919 r., k. 118.

${ }^{68}$ M. Krotofil, Ukraińska Armia Halicka, s. 85-86 ; Я. Тинченко, Панциирні потяги, s. 96.

${ }^{69}$ M. Krotofil, Ukraińska Armia Halicka, s. 85-86.

${ }^{70}$ I. Карпинець, Історія 8-ої Галицьької бригади, 12/1933, s. 16.; T. Wawrzyński, Akta dotyczace wojskowych dziejów Lwowa w latach 1912-1939 w zbiorach Centralnego Archiwum Wojskowego, [w:] "Studia i materiały do historii wojskowości”, t. XXXVI, 1994, s. 311.

71 Л. Шанковський, Украӥнська Галииька армія, s. 293-294.

${ }^{72}$ M. Krotofil, Ukraińska Armia Halicka, s. 52, 86.

${ }^{73}$ I. Карпинець, Історія 8-ої Галицької бригади, 5/1935, s. 19.
} 
26 грудня 1918 р. він займав посади конструктора і одночасно коменданта цього бронепотягу. Згодом його замінив Теодор Швець. На початках цей потяг тільки називався “панцерним”. Він складався з паровозу, критого залізними бляхами, двох вантажних вагонів, одного обшитого залізними бляхами та другого - укріпленого залізними порогами. Цей вагон мав одну гармату й три кулемети. Аби вести стрільбу безпосередньо з вагону його тильна стіна до половини була вирізана. Окрім “бойових" вагонів до складу бронепотягу причепили кілька інших вагонів. В двох вантажних розміщувалися технічний відділ і залізничні рейки. В службовому знаходилась польова кухня і проживали сапери та рахунковий підстаршина. До рухомого складу потягу входили ще два вагони навантажені вугіллям. Кулемети обслуговували 6 кулеметників, гармату - 3 артилеристи. Командував ними хорунжий О. Верхола. Технічний відділ складався з 8 осіб. За роботу паровозу відповідали машиніст з помічником. Серед вояків цей бронепотяг отримав назву “Люся"74. Перше бойове хрещення бронепотяг “Ч. 2” отримав 26 грудня 1918 р. біля Любіня Великого ${ }^{75}$. Після захоплення Любіня бронепотяг вирушив до Басівки під Львовом. Тут він перейшов під командуванням “Групи Щирець”. Базою бронепотяга стала станція Ставчани, де він перебував до 13 січня 1919 р. Саме тут у Ставчанах бронепотяг зазнав модернізації. Команді вдалось замінити старий паротяг на броньований та збільшила вогневу міць до 5 кулеметів. На станції команда поповнила запаси необхідної амуніції до гармати ${ }^{76} .313$ січня до першої половини лютого 1919 р. бронепотяг підпорядковувався команді групи в Рудках, або безпосередньо штабу 8-ї

\footnotetext{
74 Там же, 12/1932, s. 23.

${ }^{75}$ І. Карпинець, Панцеерний потяг ч. 2, “Історичний календар-альманах на 1936 р.”, Львів 1935, s. 83.

76 Там же, s. 84.
} 
Самбірської бригади ${ }^{77}$. У січні 1919 р. базою для бронепотягу Ч. 2 знову став Любінь Великий. На його озброєнні - 8 кулеметів та гармата. Технічним відділом потягу далі керував хорунжий О. Верхола. Після втрати Великого Любіня базою стала станція Комарно-Бучали ${ }^{78} .17$ лютого бронепотяг перекинули з Комарна через Самбір-Стрий до Щирця, щоб той взяв участь у наступі на Любінь-Фільварок Добаківський, який проводила 7 Львівська бригада. Наступ був невдалим. Від цього часу до 15 травня бронепотяг підпорядковувався 7 бригаді.

В середині березня 1919 р. О. Верхола привіз з Дрогобича новий бронепотяг збудований четарем М. Солодухою на верстатах “Галіції”, якому також присвоїли порядковий номер “Ч. 2". Цей бронепотяг брав участь у відомій “виправі за старшинами” до Стрия у квітні 1919 р. і придушенні Дрогобицького бунту. За поїздку до Стрия Т. Швеця і О. Верхолу заарештували однак за військові заслуги незабаром звільнили. Вже 19-20 квітня 1919 p. бронепотяг “Ч. 2” повернувся до Щирця. На шляху між станціями Пустомити і Глинна-Наварія відбувся бій з поляками де декількох вояків і Т. Швеця було поранено ${ }^{79}$.

НКГА у ході травневого відступу 1919 р. приділила бронепотяг “Ч. 2" до 7 Львівської бригади отамана Альфреда Бізанца. Вже 15 травня з III ГК його направили до розташування 8 бригади. Наступного дня бронепотяг виїхав із Самбора в напрямку до Хирова. Поблизу станції Надиби-Воютичі під с. Сусідовичі провів бій з польською батареєю ${ }^{80}$. Під час бою зазнав двох прямих попадань, які не заподіяли йому жодної шкоди. 17 травня полякам вдалось відрізати бронепотяг від основних сил українців

\footnotetext{
77 Там же, s. 85.

${ }^{78}$ I. Карпинець, Історія 8-ої Галицької бригади, 2/1933, s. 21.

${ }^{79}$ I. Карпинець, Панцеерний потяг ч. 2, s. 85-87.

${ }^{80}$ Там же, s. 87-88.
} 
і тому команда прийняла рішення підірвати його. 3 усього майна лише кулемети вдалось забрати з собою ${ }^{81}$.

17 травня 1919 р., після знищення панцерного потягу “Ч. 2” його команда займалася виловлюванням дезертирів в районі групи “Гофмана". Вже наступного дня з Дрогобича вона отримала свій попередній “імпровізований” бронепотяг. Поблизу міста, щоб не потрапити до полону, команда залишила і його, зіпсувавши при цьому гармату, кулемети знову вдалось забрати з собою. Сам паротяг запалили і пустили повним ходом на станцію. Команда подалася на Стрий, а потім потягами перебралася до Станіслава, де знову отримала “імпровізований” потяг з російською гарматою. Звідси на ньому вони виїхали до Калуша. По дорозі на Станіславів через перевантаженість колій, відступаючими ешелонами, команда прийняла рішення знищити і цей бронепотяг. Після цього вони попрямували на Галич, звідти на Нижнів де їх розподілили до піхотних частин ${ }^{82}$.

Протягом 14-15 травня 1919 р. на лінії фронту 8 Бригади діяв ще один бронепотяг під командуванням Осипа Бережницького. Він складався з 4 вагонів (всередині муровані), на озброєнні - 4 кулемети і гармата ${ }^{83}$. Однак більше відомостей про цей потяг немає.

Є відомості про існування власного бронепотягу у так званої “Команчецької республіки”, що охоплювала 30 сіл у південній частині Сяноцького повіту. Місцем його дислокації стало с. Вислоця. Він складався з локомотиву та двох вантажних вагонів, викладених цеглою, і проводив бойове чергування на залізничній лінії Лунків-Загір' я ${ }^{84}$.

\footnotetext{
${ }^{81}$ I. Карпинець, Історія 8-ої Галиизької бригади, 5/1925, s. 19-20.

82 Там же, 7-8/1935, s. 22-23.

83 Там же, 4/1935, s. 18.

84 Л. Шанковський, Українська Галицьька армія, s. 178.
} 
Поряд 3 власним будівництвом частину бронепотягів Галицька армія здобула у ворога. 10 грудня 1918 р. на ст. Брюховичі вдалось захопити бронепотяг ${ }^{85}$. Вже через кілька днів, 20 грудня - біля Малої Кологориці здобуто ще один бронепотяг: паротяг 3 гарматою і амуніцією ${ }^{86}$. Наступного дня біля с. Гориці захоплено ще один: вагон з гарматою і амуніцією, паротяг з іншим вагоном утік ${ }^{87}$. В ході Чортківської наступальної операції 24 червня 1919 р. після захоплення Ожидова і Белзця серед трофеїв був один бронепотяг ${ }^{88}$. Вже наступного дня поляки знову втратили бронепотяг ${ }^{89}$.

Зрозуміло, що і українці втрачали в боях свої потяги. Так 9 листопада 1918 р. поляки здобули під Скниловом один потяг, який перевозив 12 гармат з амуніцією ${ }^{90}$. Наприкінці листопада 1918 p. біля Устриків - ще один потяг, який складався з 10 вагонів, 2 гармат, 8 конів. В полон взято 80 вояків і 3 поранених офіцерів. В боях за Львів відзначився бронепотяг підполковника Свободи. Ним було здобуто український бронепотяг на лінії між Сокалем і Ярославом. Разом з тим багато амуніції і іншого військового майна ${ }^{91}$.

38 липня 1919 р., напередодні переходу за Збруч, бронепотяги почали підпорядковуватись залізнодорожному референтові ${ }^{92}$.

${ }^{85}$ М. Кищикевич, Коротка історія I куреня X-ої Бригади, “Літопис Червоної Калини", Львів 10/1937, s. 15.

86 Український голос, 22 грудня 1918, cz. 27, s. 1.

87 Дрогобицький листок, 28 грудня 1918, cz. 7-8, s. 5 ; Нове життя, 22 грудня 1918, cz. 22, s. 1.

88 Чортківська офензива, Мюнхен 1953, s. 36.

89 Є. Яворівський, Чортківська офензива $і$ відворот за Збруч в освітленні Начальної Команди, “Літопис Червоної Калини”, 12/1935, s. 7.

${ }^{90}$ AAN, nr 38, sygn. PP II/193, «Głos Narodu»10.11.1918, Ostatnie wiadomości ze Lwowa.

${ }^{91}$ AAN, nr 38, sygn. PP II/193, «Głos Narodu» 26.11.1918, Komunikat wojskowy. ${ }^{92}$ CDIAU, kol. 9, MF 87300, Naczelna Komanda Halyckoi Armii. Orhanizacijni schemy, wykazy stanu, rozkazy, dennyk wijskowych podij na fronti. Naczelna 
Під час відступу на Наддніпрянщину, за наказом командування ГА усі бронепотяги довелось знищити. Це пов'язано з тим, що ширина колії за Збручем не дозволяла галичанам використовувати на ній потяги австрійського чи німецького виробництва.

Бронепотяги, які використовувала Галицька армія вже за Збручем, були виготовлені на російських заводах, мали надійний броньований захист і потужне озброєння. Кулемети (зазвичай до 20) розміщувалися у броньованих баштах, здебільшого в бортах, мали запас боєприпасів на кулемет 10-14 лент (по 100 набоїв). Гармати, здебільшого дві-чотири 76 мм на бронеплощадках, з боєзапасом на кожну по 200-250 гранат. Бронепотяги оснащувались окрім того зенітною 40 мм автоматичною гарматою. Основним недоліком таких бронепотягів стала залежність від води і палива (звичайна добова потреба - 1 тис. відер води і 6,5 тонн вугілля). Швидкість пересування тогочасного бронепотяга становила: похідна - 25-45 км/год, бойова 8-10 км. Бронепотяг міг перевозити десант: загін піхоти (сотня) - 165 багнетів та чету кінноти (47 шабель). Основне завдання бронепотягів на Наддніпрянщині полягало у забезпеченні прориву оборони супротивника у взаємодії 3 піхотою і кіннотою. Вони брали активну участь у переслідуванні ворога, захопленні та утриманні залізничних вузлів, прикритті відступаючих частин ${ }^{93}$.

За Збручем галичани продовжували захоплювати бронепотяги вже у більшовиків. Наприкінці липня 1919 р. під Загруддям на залізничному шляху, що веде з Проскурова до Шепетівки вдалось спільними зусиллями 4, 7 та 8 бригад здобути два більшовицькі бронепотяги ${ }^{94}$, 36 гарматами і 22 кулеметами, які розміщувалися у спеціально збудованих вежах. Спочатку трофейні бронепотяги

Intendatura UHA. Kancelaria Prezydium Ukrainskoi Nacionalnoi Rady. 19161920, k. 125.

${ }^{93}$ П. Ткачук, Сухопутні війська, s. 203.

${ }^{94}$ Є. Бородієвич, В чотирикутнику смерти. Причинки до трагедії УГА на Великій Украӥні. (Із воєнного записника 3-тьої бригади), Нью-Йорк 1975, s. 24. 
скеровали до II ГК в Проскурові, де перший потяг під назвою “Стрілець” перейменовали на "Галичину”. Його здобув III курінь 8 Самбірської бригади у Жмеринці. Цей бронепотяг згодом прикривав відступ Галицької армії на Наддніпрянщині у січні 1920 р. Другий - “Черепаха”, його незабаром відправили у розпорядження НКГА 95 . За іншими даними бронепотяг назвали не "Черепахою", а “Золочівкою"96. Але далі про його долю нічого не відомо.

У Жмеринці вдалось захопити ще один бронепотяг “Вільна Україна", який приділили до I Бригади УСС. Вже у грудні 1919 р. його захопили поляки на лінії Шепетівка-Козятин і перейменувала на “Довбур”. Під час наступу на Київ, 8 серпня у Жмеринці здобуто ще 4 бронепотяги ${ }^{97}$. За іншими даними це сталося 9 серпня 1919 p. ${ }^{98} 20$ серпня в боях за Бердичів I ГК здобув ще два бронепотяги ${ }^{99}$. Вже в Києві 31 серпня 1919 р. галичани захопили два більшовицькі бронепотяги "Гондзє” i “Троцький”"100. Однак про використання трофейних бронепотягів, здобутих у серпні 1919 р. у лавах Галицької армії нічого не відомо.

Отже, історія бронепотягів Галицької армії була короткою але наповненою постійними військовими сутичками, як $з$ поля-

${ }^{95}$ О. Станімір, Моя участь у визвольних змаганнях 1917-1920, Торонто 1966, s. 89; 3 XIV бригадою на Великій Україні, “Літопис Червоної Калини”, 7-8/1935, s. 4; Л. Шанковський, Украӥнська Галицька армія, s. 293-294.

96 Д. Микитюк, Четверта Золочівська Бригада УГА, [w:] Золочівщина минуле і сучасне. Розвідки, спомини, публікації, пам'ятки, постаті, red.: М. Дубаса, Львів 2006, s. 177.

${ }^{97}$ CDIAU, fond 309, op. 1. poz. 1564, Wospominanija czotarja ukraińskoi halickoi armii Lanczuka Iwana "Kriwawym szlachom III kurenja 5 sokalskoi bryhady ukraińskoi halickoi Armii 1918-1920 rr.”, k. 18-19.

${ }^{98} \mathrm{BN}$, Kolekcija dokumentiw Naukowoho towarystwa imeni T. Szewczenka, mf 87501, Dzienniki i wspomnienia dotyczace lat 1917-1920, k.14.

99 Денник Начальної Команди Української Галицької армії, Нью-Йорк 1974, s. 32.

${ }^{100}$ CDIAU, fond 309, op. 1. poz. 1693, Statja studentki uczytelskoi seminarii w Peremyszlie Onysko Hali “Spomyny brata, czotarja UHA”, k. 38. 
ками, так і більшовиками. Через недосконалість їхньої конструкції, відсутності можливостей для побудови справжніх “фортець на залізницях", бронепотяги не змогли в повній мірі виконати покладені на них завдання, хоча особовий склад володів усіма професійними і бойовими якостями аби виконувати службу на високому рівні.

\section{Bibliografia}

1. AAN, nr 38, Centralna Agencja Polska w Lozannie, sygn. PP II/193, Sprawy wojskowe i działania wojenne w kraju i na kresach. (Sprawy wojskowe w Galicji. Walki w Galicji Wschodniej. 6.11.1918-31.12.1918).

2. AAN, nr 45, Kolekcje opracowań i odpisów dokumentów dotyczących stosunków Polski z Litwą, Lotwą, Rosyjską Republiką Radziecką, Ukrainą, sygn. 57, Odpis do Ministerstwa spraw zewnętrznych. Raport oficera tacznikowego w Budapeszcie majora Tobaczyńskiego dnia 9.I.1919.

3. BN, Kolekcija dokumentiw Naukowoho towarystwa imeni T. Szewczenka, MF 87299, Państwowy Sekretariat Spraw Wojskowych. Sprawy kadrowe korpusu oficerskiego i podoficerów Ukraińskiej Armii Galicyjskiej. Organizacja Stużby Kwatermistrzowskiej. 1919.

4. BN, Kolekcija dokumentiw Naukowoho towarystwa imeni T. Szewczenka, MF 87300, Naczelne Dowództwo Armii Galicyjskiej (NKGA). Schematy organizacyjne, wykazy stanu, rozkazy, dziennik wydarzeń frontowych pol. III 1916. Naczelna Intendentura Ukraińskiej Armii Galicyjskiej. Kancelaria Prezydium Ukraińskiej Rady Narodowej. 1916-1920.

5. BN, Kolekcija dokumentiw Naukowoho towarystwa imeni T. Szewczenka, MF 87501, Dzienniki i wspomnienia dotyczace lat 1917-1920.

6. BN, Kolekcija dokumentiw Naukowoho towarystwa imeni T. Szewczenka, MF 92062, Ministerstwo Komunikacji UNR i Stowarzyszenie pracowników Ministerstwa: spisy osób, okólniki, raporty, korespondencja, 1919.

7. CDAWOW, fond 2188, op. 1, poz. 15, Operatywni zwedenia wijskowych hrup pro chid wojennych dij, bojowyj, prodowolczyj stan wijsk i zabezpieczennia ich zbrojeju. Statystyczni widomosti pro osobowyj sktad korpusiw i hrup.

8. CDAWOW, fond 2188, op. 1, poz. 18, Operatywni donesennia wijskowych hrup ta rozporiadżenja Naczalnoji Komandy pro roztaszuwannia wijsk $i$ chid wojennych dij. 
9. CDAWOW, fond 2188, op. 1, poz.19, Operatywni donesenia wijskowych hrup ta rozporiadżenia Naczalnoi Komandy ukraińskoho wijska pro chid wojennych dij ta roztaszuwania wijsk.

10. CDAWOW, fond 2192, op. 1, poz. 1, Lystuwannia z NKHA ta nakazy po Armii pro orhanizaciju 4-ho ta 5-ho korpusiw, pro pokraszennia roboty sztabiw, pryznaczennia na slużbu, zwernennia delehacji politycznych, proswitnych ta ekonomicznych orhanizacij Drohobyckoho powitu pro zwilnennia powitu wid rekwizycij ta in.

11. CDAWOW, fond 2192, op. 1, poz. 2, Lystuwannia z NKHA, nakazy po Armii pro wydilennia kosztiw dla potreb Armiji, pryznaczennia na slużbu, wijskowu mobilizaciju starszyn, widnoszennia wijska do cywilnoho naselennia, wijskowi dii w Armii ta in.

12. CDAWOW, fond. 2192, op. 2, poz. 4, Nakazy ta rozporiadżennia Dyktatora ZoUkrainy, widomosti ta zwity uriadowciw ta wijskowych naczalnykiw pro stanowyszsze w Halyczyni. Lystuwannia z wijskowymy ustanowamy, Czerwonym Chrestom pro postaczannia HA furażem, prodowolstwom, medykamentamy, statut ukraińskoho rachunkowo-strileckoho towarystwa "Sicz", ankety ta poswidky sluzbowciw wijskowych ustanow HA.

13. CDIAU, fond 309, op. 1. poz. 1564, Wospominanija czotaria ukraińskoi halickoi armii Lanczuka Iwana "Kriwawym szlachom III kurenja 5 sokalskoi bryhady ukraińskoi halickoi Armii 1918-1920 rr.".

14. CDIAU, fond 309, op. 1. poz. 1693, Statja studentki uczytelskoi seminarii w Peremyszlie Onysko Hali "Spomyny brata, czotarja UHA".

15. CDIAU, fond 581, op. 1, poz. 146, Nakazy ta operatywni zwity naczalnoji intendatury Halyckoji Armiji pry Komandi Etapu Armiji ta okrużnych komanduwań w Kolomyji, Sambori ta Czortkowi.

16. CDIAU, kol. 9, MF 87300, Naczalna Komanda Halyckoji Armiji. Orhanizacijni schemy, wykazy stanu, rozkazy, dennyk wijskowych podij na fronti. Naczelna Intendatura UHA. Kancelaria Prezydium Ukrainskoi Nacionalnoi Rady. 1916-1920.

17. Klimecki M., Polsko-ukraińska wojna o Lwów I Galicję Wschodnia 1918-1919, Warszawa 2000.

18. Krotofil M., Ukraińska Armia Halicka 1918-1920. Organizacja, uzbrojenie, wyposażenie i wartość bojowa sił zbrojnych Zachodnio-Ukraińskiej Republiki Ludowej, Torun 2002.

19. Wawrzyński T., Akta dotyczace wojskowych dziejów Lwowa w latach 1912 1939 w zbiorach Centralnego Archiwum Wojskowego, [w:] "Studia i materiały do historii wojskowości”, t. XXXVI, 1994. - s. 309-312. 
20. Бемко В., Держсавний секретаріат військових справ, [w:] Украйнська Галицька армія. У 40-річчя ї̈ участи у Визвольних Змаганнях в 1918-1920 рр. Матеріяли до історіï, red. Д. Микитюк, Вінніпег 1958, t. 1. - s. 61-70.

21. Боберський І., Щоденник, 1918-1919 pp., red.: Ю. Мицик, Київ 2003.

22. Бородієвич Є., В чотирикутнику смерти. Причинки до трагедії УГА на Великій Украӥні. (Із воєнного записника 3-тьої бригади), Нью-Йорк 1975.

23. Буцманюк Ю., Залізнодорожна Військова Управа (ЗУВ), [w:] Українська Галицька армія. У 40-річчя ї̈ участи у Визвольних Змаганнях в 1918 1920 рр. Матеріяли до історї̈, red. Д. Микитюк, Вінніпег 1958, t. 1. - s. 297-305.

24. Галицький Голос, 1919.

25. Д. М. Короткі історичні нариси бригад УГА [w:] Украӥнська Галицька армія. У 40-річчя ї̈ участи у Визвольних Змаганнях в 1918-1920 рр. Матеріяли до історії, red.: Д. Микитюк, Вінніпег 1958, t. 1. - s. 85-126.

26. Денник Начальної Команди Української Галиџької армії, Нью-Йорк 1974.

27. Дедик О., Війна на залізничних коліях. Панцерники УГА, “Літопис Червоної Калини”, Львів 1992.

28. Дєдик О., Гонитва за мостами: боротьба за переправи через Дністер під час українсько-польської війни 1918-1919 років, “Цитаделя. Львівський мілітарний альманах", Львів 2010, s. 25-35.

29. Дрогобицький листок, 1918.

30. 3 XIV бригадою на Великій Україні, “Літопис Червоної Калини”, 1935.

31. Карпинець І., Історія 8-ӧ̈ Галицької бригади, “Літопис Червоної Калини”, za 1932-1935.

32. Карпинець I., Панцерний потяг ч. 2, “Історичний календар-альманах на 1936 р.”, Львів 1935.

33. Кищикевич М., Коротка історія I куреня X-ої Бригади, “Літопис Червоної Калини”, Львів 1937.

34. Микитюк Д., Четверта Золочівська Бригада УГА, [w:] Золочівщина минуле і сучасне. Розвідки, спомини, публікаиії, пам'ятки, постаті, red.: М. Дубаса, Львів 2006.

35. Міхула О., Державні залізниці 3.О.У.Н.Р., “Літопис Червоної Калини” Львів 1935.

36. Монджейовський Д., Залізно-дорожне Депо У.Г.А., “Літопис Червоної Калини”, Львів 1938.

37. Народ, 1919. 
38. Нове життя, 1918-1919.

39. Ортинський В., Силові структури Західно-Украӥнської Народної республіки, Львів 2004.

40. Печенюк С., Бронепотяги - фортеці на рейках, “Технічні досягнення минулого", Київ 2010, s. 28-40.

41. Реєнт О., Рубльов О., Українські визвольні змагання 1917-1921 рр., Київ 1999, t. 10.

42. Садлич I., На панщ̧иризі під Хировом, “Літопис Червоної Калини”, Львів 1939.

43. Станімір О., Моя участь у визвольних змаганнях 1917 - 1920, Торонто 1966.

44. Тимченко Р., Воєнно-політичне й економічне співробітництво УНР $i$ ЗОУНР в першій половині 1919 р., “Український історичний збірник”, Київ 2010, s. 202-215.

45. Тинченко Я., Панциирні потяги, панцерники та залізничні війська у Визвольній війні 1917-1920 рр.: науково-популярне видання, Київ 2012.

46. Ткачук П., Сухопутні війська Збройних сил Украӥни доби революиії 1917 1921 рр., Львів 2009.

47. Український голос, 1918.

48. Футулуйчук Д., Організаційно-правові засади участі залізничної жандармерії у військово-організаційному і транспортно-технічному забезпеченні воєнних операцій ЗУНР у 1918-1920 рр., "Науково-інформаційний вісник”, 6/2012, s. 87-93.

49. Футулуйчук Д., Участь жандармерії в державному будівниитві та захисті суверенітету ЗУНР, [w:] дис... канд.іст.наук: 20.02.22, Львів 2004.

50. Цегельський Л., Від легенд до правди, Львів 2003.

51. Чортківська офензива, Мюнхен 1953.

52. Шанковський Л., Украӥнська Галицька армія, Львів 2010.

53. Яворівський Є., Чортківська офензива і відворот за Збруч в освітленні Начальної Команди, “Літопис Червоної Калини”, Львів 1935. 